\title{
DETERMINANTS OF INTRA-INDUSTRY AGRI-FOOD TRADE IN THE VISEGRAD COUNTRIES
}

\author{
A. JÁMBOR* \\ Dept. of Agricultural Economics and Rural Development, Corvinus University of Budapest, \\ 1093 Budapest, Fővám tér 8. Hungary
}

(Received: 5 November 2012; accepted: 21 January 2013)

\begin{abstract}
The article analyses patterns and country-specific determinants of Visegrad Countries' agri-food trade with the European Union. Literature focusing on the country-specific determinants of vertical and horizontal intra-industry trade is rather limited and those analysing agricultural (or agri-food) trade are extremely rare. Therefore, the paper seeks to contribute to the literature by covering the latest theories and data available on the topic to provide up to date results and suggestions. Moreover, it seeks to identify the determinants of horizontal and vertical intra-industry trade of the Visegrad Countries after EU accession. According to the results determinants of horizontal and vertical intra-industry differ and suggest that economic size is positively, while distance is negatively related to both sides of intra-industry trade. However, the relationship between vertical intra-industry trade and differences in factor endowments as well as foreign direct investment is ambiguous.
\end{abstract}

Keywords: Visegrad Countries, intra-industry trade, determinants

The growing importance of the determinants of intra-industry trade (IIT) over the last two decades is evident from the literature, though just a limited amount of studies is focused on the country-specific determinants of vertical and horizontal intra-industry trade. GREENAWAY and co-workers (1994) were the first to analyse country-specific factors of horizontal and vertical intra-industry trade in the UK and found that vertical IIT is more important in the UK than horizontal IIT and that the inter-country pattern of vertical IIT is systematically related to a range of explanatory variables. Aturupane and co-workers (1999) searched for the determinants of horizontal and vertical intra-industry trade between Eastern Europe and the European Union and showed that the determinants of the two types of IIT are likely to differ, with vertical IIT being more a reflection of endowment or technology-based factors, and horizontal IIT being more dependent on factors, such as scale economies and imperfect competition.

KANDOGAN (2003) analysed IIT of transition countries and concluded that variables from the increasing returns trade theory, such as scale economies, similarity of income levels, and number of varieties produced play important roles in horizontal IIT, whereas factors, such as comparative advantage or dissimilarity in income levels, are more related to vertical IIT. ZHANG and Li (2006) investigated country-specific factors of intra-industry trade in China's manufacturing and underlined that the more countries differ in relative country size and relative factor endowments, the less likelihood there is for IIT and horizontal IIT. They also emphasised that difference between countries in relative factor endowments leads to more inter-industry trade, which in turn suppresses IIT and vertical IIT.

\footnotetext{
* To whom correspondence should be addressed.

Phone: +36 148251 80; fax: +36 148254 28; e-mail: attila.jambor@uni-corvinus.hu
} 
FERTŐ $(2005 ; 2007)$ analysed Hungarian intra-industry agri-food trade patterns with the EU15 and confirmed the comparative advantage explanation of vertical IIT, while stressing that using a measure of IIT that reflects the level of trade produces better regression results than those based on the degree or share of IIT.

CAEtano and Galego (2007) were searching for the determinants of intra-industry trade within an enlarged Europe and found that determinants of horizontal and vertical IIT differed, although both had a statistically significant relationship with a country's size and foreign direct investment. TURKCAN and ATES (2010) investigated for the determinants of IIT in the U.S. Auto-Industry and beside confirming that determinants of horizontal and vertical IIT differ, showed that vertical IIT is positively associated with average market size, differences in market size, differences in per capita GDP, outward FDI, and distance, while it is negatively correlated with the bilateral exchange rate variable.

Leitao (2011) examined intra-industry trade patterns in the Portuguese automobile sector and concluded that intra-industry trade occurred more frequently among countries that were similar in terms of factor endowments as well as pointed out that no positive statistical association existed between HIIT and Heckscher-Ohlin variables. AmbroziaK (2012) investigated the relationship between FDI and IIT in the Visegrad Countries and found that FDI stimulated not only VIIT in the region but also HIIT.

It is evident from the above that there is a wide range of literature generally analysing intra-industry trade patterns but one important shortcoming of such literature is that it ignores the distinction between horizontal and vertical IIT and ignores the fact that they may have different determinants. Literature focusing on the country-specific determinants of vertical and horizontal intra-industry trade is rather limited and those analysing agricultural (or agrifood) trade are extremely rare.

The paper seeks to contribute to the scant literature of the field in two ways. First, it covers the latest theories and data available on the topic to provide up to date results and suggestions. Second, it seeks to identify the determinants of horizontal and vertical intraindustry trade of the Visegrad Countries (Czech Republic, Hungary, Poland, and Slovakia) after EU accession.

\section{Materials and methods}

Several methods exist to measure intra-industry trade. First, the classical Grubel-Lloyd (GL) index has to be mentioned, which is expressed formally as follows (GRUBEL and LLOYD, 1975):

$$
\mathrm{GL}_{\mathrm{i}}=1-\frac{\left|\mathrm{X}_{\mathrm{i}}-\mathrm{M}_{\mathrm{i}}\right|}{\left(\mathrm{X}_{\mathrm{i}}+\mathrm{M}_{\mathrm{i}}\right)}
$$

where $\mathrm{X}_{\mathrm{i}}$ and $\mathrm{M}_{\mathrm{i}}$ are the value of exports and imports of product category $\mathrm{i}$ in a particular country. The GL index varies between 0 (complete inter-industry trade) and 1 (complete intra-industry trade) and can be aggregated to the level of countries and industries as follows:

$$
\mathrm{GL}=\sum_{\mathrm{i}=1}^{\mathrm{n}} \mathrm{GL}_{\mathrm{i}} \mathrm{w}_{\mathrm{i}} \text { where } \mathrm{w}_{\mathrm{i}}=\frac{\left(\mathrm{X}_{\mathrm{i}}+\mathrm{M}_{\mathrm{i}}\right)}{\sum_{\mathrm{i}=1}^{\mathrm{n}}\left(\mathrm{X}_{\mathrm{i}}+\mathrm{M}_{\mathrm{i}}\right)}
$$


where $\mathrm{w}_{\mathrm{i}}$ comes from the share of industry $\mathrm{i}$ in total trade. However, several authors criticised the GL-index, for five main reasons: (1) aggregate or sectoral bias, (2) trade imbalance problem, (3) geographical bias, (4) inappropriateness to separate horizontal and vertical intra-industry trade (HIIT and VIIT), (5) inappropriateness for treating dynamics. Detailed discussion of these problems but the fourth would distract from the basic aim of this paper; a comprehensive review can be found in FERTÖ (2004).

The fourth problem of the GL index is given by the joint treatment of horizontal and vertical trade. Literature suggests several possibilities for solving this problem. Among these solutions, the most widespread one is based on unit values developed by ABD-EL RAHMAN (1991). The underlying presumption behind unit values is that relative prices are likely to reflect relative quantities (STIGLITZ, 1987). According to the widespread view in the literature based on this presumption, horizontally differentiated products are homogenous (perfect substitutes) and of the same quality, while vertically differentiated products have different prices reflecting different quality (FALVEY, 1981). According to the method of GREENAWAY and co-workers (1995), a product is horizontally differentiated if the unit value of export compared to the unit value of import lies within a $15 \%$ range at the five digit SITC level. If this is not true, the GHM method is talking about vertically differentiated products. Formally, this is expressed for bilateral trade of horizontally differentiated products as follows:

$$
1-\alpha \leq \frac{\mathrm{UV}_{\mathrm{i}}^{\mathrm{X}}}{\mathrm{UV}_{\mathrm{i}}^{\mathrm{M}}} \leq 1+\alpha
$$

where UV means unit values, $X$ and $M$ mean exports and imports for goods $i$ and $\alpha=0.15$. If this equation is not true, GHM method talks about vertically differentiated products. Furthermore, GREENAWAY and co-workers (1994) added that results coming from the selection of the $15 \%$ range do not change significantly when the spread is widened to $25 \%$. BLANES and MARTín (2000) developed the model further and defined high and low VIIT. According to their views, low VIIT means that the relative unit value of a good is below the limit of 0.85 , while unit value above 1.15 indicates high VIIT.

Based on the logic above, the GHM index comes formally as follows:

$$
\operatorname{GHM}_{\mathrm{k}}^{\mathrm{p}}=\frac{\sum_{\mathrm{j}}\left[\left(\mathrm{X}_{\mathrm{j}, \mathrm{k}}^{\mathrm{p}}+\mathrm{M}_{\mathrm{j}, \mathrm{k}}^{\mathrm{p}}\right)-\left|\mathrm{X}_{\mathrm{j}, \mathrm{k}}^{\mathrm{p}}-\mathrm{M}_{\mathrm{j}, \mathrm{k}}^{\mathrm{p}}\right|\right]}{\sum_{\mathrm{j}}\left(\mathrm{X}_{\mathrm{j}, \mathrm{k}}+\mathrm{M}_{\mathrm{j}, \mathrm{k}}\right)}
$$

where $\mathrm{X}$ and $\mathrm{M}$ stand for export and import, respectively, while $\mathrm{p}$ distinguishes horizontal or vertical intra-industry trade, $\mathrm{j}$ is for the number of product groups and $\mathrm{k}$ is for the number of trading partners $(\mathrm{j}, \mathrm{k}=1, \ldots \mathrm{n})$.

There is another method in the literature to distinguish HIIT and VIIT. FonTAGNÉ and FREUDENBERG (FF method, 1997) categorize trade flows and compute the share of each category in total trade. They defined trade to be "two-way" when the value of the minority flow represents at least $10 \%$ of the majority flow. Formally:

$$
\frac{\operatorname{Min}\left(\mathrm{X}_{\mathrm{i}}, \mathrm{M}_{\mathrm{i}}\right)}{\operatorname{Max}\left(\mathrm{X}_{\mathrm{i}}, \mathrm{M}_{\mathrm{i}}\right)} \geq 10 \%
$$


If the value of the minor flow is below $10 \%$, trade is classified as inter-industry in nature. If the opposite is true, the FF index comes formally as:

$$
\mathrm{FF}_{\mathrm{k}}^{\mathrm{p}}=\frac{\sum_{\mathrm{j}}\left(\mathrm{X}_{\mathrm{j}, \mathrm{k}}^{\mathrm{p}}+\mathrm{M}_{\mathrm{j}, \mathrm{k}}^{\mathrm{p}}\right)}{\sum_{\mathrm{j}}\left(\mathrm{X}_{\mathrm{j}, \mathrm{k}}+\mathrm{M}_{\mathrm{j}, \mathrm{k}}\right)}
$$

After calculating the FF index, trade flows can be classified as follows: horizontal twoway trade, vertical two-way trade and one-way trade.

All the indices shown above measure the share of intra-industry trade instead of its level, which is a much better index as NILSSON (1997) suggests. According to the author, IIT should be divided by the number of product groups in total trade, resulting in an average IIT by product group. Applying this logic to horizontal and vertical IIT, the Nilsson index is formally expressed as:

$$
\mathrm{N}_{\mathrm{k}}^{\mathrm{p}}=\frac{\sum_{\mathrm{j}}\left[\left(\mathrm{X}_{\mathrm{j}, \mathrm{k}}^{\mathrm{p}}+\mathrm{M}_{\mathrm{j}, \mathrm{k}}^{\mathrm{p}}\right)-\left|\mathrm{X}_{\mathrm{j}, \mathrm{k}}^{\mathrm{p}}-\mathrm{M}_{\mathrm{j}, \mathrm{k}}^{\mathrm{p}}\right|\right]}{\mathrm{n}^{\mathrm{p}}}
$$

where the numerator equals to that of the GHM index, while $\mathrm{n}$ refers to the number of product groups in total trade. NiLsson (1997) argues that his measure provides a better indication of the extent and volume of IIT than GL-type indices and is more appropriate in cross-country IIT analyses.

As described in the literature review, theory argues that HIIT and VIIT determinants differ. This may explain why econometric analyses having total (horizontal and vertical) IIT as their dependent variable may be mis-specified. Therefore, the determinants of HIIT and VIIT will now be investigated separately for the case of Visegrad Countries agri-food trade with EU27.

The balanced panel data set contains VC trade with each and every EU member state for six years, resulting in 648 observations. As the majority of literature regresses a measure of IIT on a range of possible explanatory variables without any predefined method, this article uses panel estimation techniques, capturing both cross-sectional and time-dependent special effects. Therefore, consistent with the literature on the determinants of IIT, hypotheses are as follows:

\section{H1. Difference in factor endowments between trading partners increases (decreases) the} share of vertical (horizontal) IIT in total trade.

The difference in factor endowments is usually measured by inequality in per capita GDP, in line with the model developed by FALVEY and KiERZKOwsKi (1987). Linder (1961) considers that countries with similar demands have similar products, consequently vertical type trade increases with differences in relative factor endowments. Factor endowments are proxied by the logarithm of absolute value of the difference in per capita GDP between Visegrad Countries and their trading partners (lnDGDPC), which is expected to be positively related to the share of vertical IIT. LnDGDPC is measured in PPP in current international dollars and data comes from the World Bank WDI database. 
H2. The smaller the difference in economic size of the two partner economies, the higher the expected IIT in their trade.

The larger the international market, the larger the opportunities for production of differentiated intermediate goods and the larger the opportunities for trade in intermediate goods. The logarithm of the average GDP of trading partners is used as a proxy for the average size of markets. LnAVGDP is measured in PPP in current international dollars and the source of data is also the World Bank WDI database. A positive sign for both horizontal and vertical IIT is expected.

\section{H3. The larger the share of foreign direct investment (FDI) in the host country, the higher the share of HIIT and VIIT.}

Multinational companies have crucial influence on IIT through their FDI activities. Investing in production facilities abroad creates the possibility to exchange products at different levels in the production stage, thereby contributing to IIT. The logarithm of the absolute difference of stocks of FDI (in billion USD) in the Visegrad Countries is used to test this hypothesis. FDI is measured in current international USD and data is coming from the WDI database. A positive sign is expected for VIIT as well as HIIT.

\section{H4. IIT is greater the closer the countries are geographically.}

The distance between countries well reflects transport costs. It is evident that the closer the countries are, the cheaper the trade is. Variable lnDIST indicates the geographic distance between the reporting country and each of its trading partners by calculating the logarithm of the distance between the capital cities of trading partners in kilometres. The source of data is the CEPII database. LnDIST is expected to be negatively related to HIIT and VIIT.

In order to test hypotheses above, the following standard panel regression model is employed:

$$
\operatorname{lnIIT}_{\mathrm{ijt}}=\alpha_{0}+\alpha_{1} \operatorname{lnDGDPC}_{\mathrm{ijt}}+\alpha_{2} \ln \operatorname{AVGDP}_{\mathrm{ijt}}+\alpha_{3} \operatorname{lnDFDI}_{\mathrm{ijt}}+\alpha_{4} \operatorname{lnDIST}_{\mathrm{ijt}}+\mathrm{v}_{\mathrm{ij}}+\varepsilon_{\mathrm{ij}}
$$

where $\operatorname{lnIIT}_{\mathrm{ijt}}$ is $\log$ of measure of total, vertical, and horizontal IIT, $\mathrm{i}=$ Visegrad Countries and $\mathrm{j}=\mathrm{EU} 27$ partner country, $\mathrm{t}=$ time; $\operatorname{lnDGDPC}_{\mathrm{ijt}}$ is the $\log$ of absolute difference in per capita GDP between $i$ and $j$. LnAVGDP $_{i j t}$ is the log of average value of GDP between $i$ and $\mathrm{j}$, while $\operatorname{lnFDI}_{\mathrm{ijt}}$ is the $\log$ of absolute difference of FDI between $\mathrm{i}$ and $\mathrm{j}$; $\operatorname{lnDIST} \mathrm{int}_{\mathrm{ijt}}$ is $\log$ of distance between the capital cities of $\mathrm{i}$ and $\mathrm{j}$. The expected signs for HIIT are $\alpha_{1}$ and $\alpha_{4}<0$, $\alpha_{2}$ and $\alpha_{3}>0$, while for vertical IIT are $\alpha_{1}, \alpha_{2}, \alpha_{3}>0$ and $\alpha_{4}<0$. Table 2 provides an overview of the details associated with variables.

In order to perform calculations based on the above equations, the article uses the Eurostat international trade database using the HS6 system (six digit breakdown) as a source of raw data. Agri-food trade is defined as trade in product groups HS 1-24, resulting in 964 products using the six digit breakdown. The article works with trade data for the period 2005-2010 due to data availability. In this context, the EU is defined as the member states of the EU27. 
Table 1. Description of independent variables

\begin{tabular}{|c|c|c|c|c|}
\hline \multirow[t]{2}{*}{ Variable } & \multirow[t]{2}{*}{ Variable description } & \multirow[t]{2}{*}{ Data source } & \multicolumn{2}{|c|}{ Expected sign } \\
\hline & & & HIIT & VIIT \\
\hline $\operatorname{lnDGDPC}$ & $\begin{array}{l}\text { The logarithm of per capita GDP absolute } \\
\text { difference between trading partners measured in } \\
\text { PPP in current international USD }\end{array}$ & $\begin{array}{l}\text { World Bank WDI } \\
\text { database }\end{array}$ & - & + \\
\hline $\operatorname{lnAVGDP}$ & $\begin{array}{l}\text { The logarithm of average GDP of trading partners } \\
\text { measured in PPP in current international USD }\end{array}$ & $\begin{array}{l}\text { World Bank WDI } \\
\text { database }\end{array}$ & + & + \\
\hline $\operatorname{lnFDI}$ & $\begin{array}{l}\text { The logarithm of FDI net inflows absolute } \\
\text { difference between trading partners measured in } \\
\text { current international USD }\end{array}$ & $\begin{array}{l}\text { World Bank WDI } \\
\text { database }\end{array}$ & + & + \\
\hline $\operatorname{lnDIST}$ & $\begin{array}{l}\text { The logarithm of absolute difference between } \\
\text { trading partners capital city measured in kilometres }\end{array}$ & CEPII database & - & - \\
\hline
\end{tabular}

\section{Results and discussion}

The use of a fixed effects model to capture country differences was rejected as a time invariant regressor (lnDIST) is incorporated in the model. Random effects models have been estimated employing generalised least squares and maximum-likelihood approaches. The most robust results in terms of statistical significance were found with the former method, therefore only this specification is reported.

Three equations were estimated in line with the three methods of measuring intraindustry trade given in the literature review. Regarding the determinants of horizontal IIT of the $\mathrm{VC}$, it is observable that all the three methods provide similar results (Table 2). LnDGDPC and $\operatorname{lnDIST}$ are negative for all estimations, while lnAVGDP and lnFDI show positive signs. It can also be seen that lnAVGDP and lnDIST are highly significant in all cases, while $\operatorname{lnDGDPC}$ and $\operatorname{lnFDI}$ are less significant (or insignificant in the case of the Nilsson-index). These results are in line with previous expectations and hypotheses on the signs of the relationship.

Table 2. Determinants of VC horizontal IIT

\begin{tabular}{lccc}
\hline Independent variable & & Dependent variable & $\mathrm{N}^{\mathrm{H}}$ \\
\cline { 2 - 4 } & $\mathrm{GHM}^{\mathrm{H}}$ & $\mathrm{FF}^{\mathrm{H}}$ & -1229.576 \\
& $-0.0041^{* *}$ & $-0.0074^{* *}$ & $(-0.41)$ \\
$\operatorname{nnd}$ & $(-2.44)$ & $(-2.67)$ & $4958.976^{* *}$ \\
$\ln$ AVGDP & $0.0036^{* * *}$ & $0.0070^{* * *}$ & $(2.47)$ \\
& $(3.36)$ & $(3.90)$ & 435.5622 \\
$\operatorname{lnFDI}$ & $0.0022^{* *}$ & $0.0031^{* *}$ & $(0.32)$ \\
& $(2.54)$ & $(2.16)$ & $-16443.66^{* * *}$ \\
lnDIST & $-0.0134^{* * *}$ & $-0.0236^{* * *}$ & $(-3.20)$ \\
& $(-5.53)$ & $(-5.83)$ & -7478.723 \\
\hline
\end{tabular}

Note: Numbers in parentheses are z statistics; significance levels are $* * *: 1 \% ; * *>5 \% ; *: 10 \%$.

Source: Calculations are based on Eurostat (2012) data 
As to the determinants of vertical intra-industry trade, results by method (see Table 3) show similar signs in all but one case (lnDGDPC is negative for the FF method but positive for the other two). All variables except lnFDI meet previous expectations on signs - lnFDI turns out to be negative, though of little significance. Another difference compared to horizontal estimations is that $\operatorname{lnDGDPC}$ is insignificant in all relations analysed. However, $\ln A V G D P$ and $\operatorname{lnDIST}$ remained strongly significant. In short, the signs of all vertical variables except for lnFDI were in line with previous expectations.

Table 3. Determinants of VC vertical IIT

\begin{tabular}{|c|c|c|c|}
\hline \multirow[t]{2}{*}{ Independent variable } & \multicolumn{3}{|c|}{ Dependent variable } \\
\hline & GHM & $\mathrm{FF}$ & $\mathrm{N}$ \\
\hline $\operatorname{lnDGDPC}$ & $\begin{array}{c}0.0020 \\
(0.53)\end{array}$ & $\begin{array}{c}-0.0016 \\
(-0.27)\end{array}$ & $\begin{array}{c}5216.692 \\
(0.98)\end{array}$ \\
\hline $\ln A V G D P$ & $\begin{array}{c}0.0194 * * * \\
(7.01)\end{array}$ & $\begin{array}{c}0.0331 * * * \\
(7.56)\end{array}$ & $\begin{array}{c}22666.31 * * * \\
(4.54)\end{array}$ \\
\hline $\operatorname{lnFDI}$ & $\begin{array}{c}-0.0034 * * \\
(-2.18)\end{array}$ & $\begin{array}{c}-0.0044 * \\
(-1.79)\end{array}$ & $\begin{array}{c}-2131.663 \\
(-1.06)\end{array}$ \\
\hline $\operatorname{lnDIST}$ & $\begin{array}{c}-0.0515 * * * \\
(-6.64)\end{array}$ & $\begin{array}{c}-0.0874 * * * \\
(-7.13)\end{array}$ & $\begin{array}{c}-72679.9 * * * \\
(-4.66)\end{array}$ \\
\hline Constant & $\begin{array}{c}-0.0188 \\
(-0.58)\end{array}$ & $\begin{array}{c}-0.0291 \\
(-0.56)\end{array}$ & $\begin{array}{c}-63460.27 \\
(-0.96)\end{array}$ \\
\hline
\end{tabular}

Note: numbers in parentheses are z statistics; significance levels are $* * *: 1 \% ; * *>5 \% ; *: 10 \%$.

Source: Calculations are based on Eurostat (2012) data

On the whole, it can be concluded that all hypotheses but the third are accepted on the basis of the results. The third hypothesis is rejected as the lnFDI variable shows negative signs for vertical IIT. It becomes evident that economic size is positively, while distance is negatively related to both sides of intra-industry trade. However, the relationship between vertical intra-industry trade and differences in factor endowments as well as foreign direct investment is ambiguous.

\section{Conclusions}

The article analysed patterns and country-specific determinants of Visegrad Countries' agrifood trade with the European Union. Three different approaches were used to calculate intraindustry trade indices (GHM, FF and the Nilsson-method), providing the basis for regressions run on the determinants of horizontal and vertical IIT.

It is verified that determinants of horizontal and vertical IIT differ and suggested that economic size is positively, while distance is negatively related to both sides of IIT. However, the relationship between vertical IIT and differences in factor endowments as well as FDI are ambiguous. In general, the results are mainly in line with initial expectations.

The research for this paper was supported by the Hungarian Scientific Research Fund Project 83119, 'Changes and determinants of Central and Eastern European agricultural trade' and by the Janos Bolyai Research scholarship of the Hungarian Academy of Sciences. 


\section{References}

ABD-EL RAhman, K. (1991): Firms' competitive and national comparative advantages as joint determinants of trade composition. Weltwirtschaftliches Archiv, 127, 83-97.

AmbroziaK, L. (2012): FDI and intra-industry trade: theory and empirical evidence from the Visegrad Countries. Int. J. Economics Business Res., 4, 180-198.

Aturupane, C., Duankov, S. \& Hoekman, B. (1999): Horizontal and vertical intra-industry trade between Eastern Europe and the European Union. Weltwirtschaftliches Archiv, 135, 62-81.

Blanes, J.V. \& Martín, C. (2000): The nature and causes of intra-industry trade: back to the comparative advantage explanation? The Case of Spain. Weltwirtschaftliches Archiv, 136, 423-441.

Caetano, J. \& Galego, A. (2007): In search for the determinants of intra-industry trade within an enlarged Europe. South-Eastern Eur. J. Econs, 2, 163-183.

EUROSTAT (2012): www.epp.eurostat.ec.europa.eu

Falvey, R. (1981): Commercial policy and intra-industry trade. J. Int. Econs, 11, 495-511.

Falvey, R. \& Kierzkowski, H. (1987): Product quality, intra-industry trade and (im)perfect competition. in: Kierzkowski, H. (Ed.) 1987. Protection and competition in international trade. Blackwell, Oxford, pp. 143161.

FerTő, I. (2004): Agri-food trade between Hungary and the EU. Századvég Publishing, Budapest, 257 pages.

FERTÖ, I. (2005): Vertically differentiated trade and differences in factor endowment - the case of agri-food products between Hungary and the EU. J. Agric. Econs, 56, 117-134.

FERTŐ, I. (2007): Intra-industry trade in horizontally and vertically differentiated agri-food products between Hungary and the EU. Acta Oeconomica, 57, 191-208.

Fontagné, L. \& Freudenberg, M. (1997): Intra-industry trade: methodological issues reconsidered. CEPII, document de travail, No. 97-01.

Greenaway, D., Hine, R. \& Milner, C. (1994): Country-specific factors and the pattern of horizontal and vertical intra-industry trade in UK. Wetwirtschaftliches Archiv, 130, 77-100.

Greenaway, D., Hine, R.C. \& Milner, C.R. (1995): Vertical and horizontal intra-industry trade: A cross-industry analysis for the United Kingdom. Economic Journal, 105, 1505-1518.

Grubel, H.G. \& Lloyd, P.J. (1975): Intra industry trade. Macmillan, London. 205 pages.

Helpman, E. \& Krugman, P. (1985): Market structure and foreign trade. Cambridge, MIT Press, 271 pages.

KAndogan, Y. (2003): Intra-industry trade of transition countries: trends and determinants. Emerging Markets Rev., $4,273-286$.

Leitao, N.C. (2011): Intra-industry trade in the automobile sector: the Portuguese experience. Argumenta Oeconomica, 2, 125-136.

LiNDER, S.B. (1961): An essay on trade and transformation, John Wiley, New York, 161 pages.

NiLsson, L. (1997): The measurement of intra-industry trade between unequal partners. Weltwirtschaftliches Archiv, $133,554-565$.

Stiglitz, J. (1987): The causes and the consequences of the dependence of quality on price. J. Econ. Lit., $25,1-48$.

TuRkCAN, K. \& AtES, A. (2010): Structure and determinants of intra-industry trade in the U.S. Auto-Industry. Journal of International and Global Economic Studies, 2, 15-46.

ZHANG, Z. \& Li, C. (2006): Country-specific factors and the pattern of intra-industry trade in China's manufacturing. J. Int. Dev., 18, 1137-1149. 